Check for updates

London

Cite this as: BMJ2020;370:m3065 http://dx.doi.org/10.1136/bmj.m3065 Published: 31 July 2020

\section{Covid-19: Sandwell Council in West Midlands sets up contact tracing, citing failures of national scheme}

\author{
Matthew Limb
}

A council in England has set up its own covid-19 contact tracing system because of a surge of local coronavirus cases and frustration with the government's NHS Test and Trace scheme.

Lisa McNally, director of public health at Sandwell Council, said that she had taken the step because four in 10 cases were going untraced and the spread of the virus risked a local lockdown.

"We need to do it ourselves. We won't be waiting to see which four people Test and Trace fails to reach-as by then it is too late," she told BBC West Midlands on 30 July. "Effective contact tracing is the only way we can separate the infected people from the non-infected people and break that chain of transmission-it's absolutely crucial."

Sandwell in the West Midlands serves a population of 327 ooo, and Public Health England data show it to be among the top 10 coronavirus hotspots in England. Infection rates rose to 32.4 in 100 ooo people in the week to 26 July, up from 23.2 in 100 ooo the previous week. New cases totalled 106 in the week to 26 July, up from 76 the previous week.

McNally said, "There is no doubt that, if cases continue to rise and they get to a level where the government feel they need to do something more significant, then a lockdown is a possibility."

\section{Workplaces}

Many of the cases in the borough have been linked to workplaces, including a McDonald's restaurant that has been closed temporarily after several employees tested positive.

McNally said feedback suggested that the government's tracing system was not working well in areas with diverse populations because of insufficient translation services. Nor was it providing all of the details required, such as about people's occupations so that workplace outbreaks could be spotted early, she said. Sandwell's tracing team began work on 29 July to fill such gaps and to exert more control over surging cases.

McNally told BBC West Midlands, "We were not getting data on the personal information of positive cases for quite a while, and we had to really lobby for that. We started getting that last week, but we immediately deployed lots of council staff from other departments into the public health team-those who could speak Punjabi, Arabic, and all other languages spoken in Sandwell, and we have got it up and running."

Sandwell aims to call all positive cases as soon as their details come in. Those contacted will be advised to self-isolate and asked about their place of work and where they have been recently, including any social events such as parties, weddings, or faith meetings. Settings with confirmed cases will be notified about the actions they need to take.

\section{Contact tracing}

NHS Test and Trace, which includes the national call centre and online system run by two private companies, Serco and Sitel, went live on 28 May. Experts say that over $80 \%$ of close contacts of infected people need to be reached for controls to be effective, but many areas, including those with the highest infection rates, fall well short of this.

Latest figures show that, of the people who tested positive and were transferred to the contact tracing system in the week ending 22 July, $81 \%$ provided details of at least one contact, up from $79 \%$ the previous week. ${ }^{1}$ Three quarters of contacts were reached and asked to self-isolate, down from $78 \%$ the previous week.

A Department of Health and Social Care spokesperson said, "In just seven weeks NHS Test and Trace has tested over 2.3 million people for coronavirus, identified nearly 39000 with the virus and reached almost 200 ooo of their close contacts, advising them to isolate to help us control the spread of the virus and save lives.

"High quality data is critical to tackle local outbreaks, and we've been sharing detailed data every day with local authorities to help them take appropriate action where necessary."

The spokesperson said that public health directors were receiving fully identifiable test, case, and contact tracing data. The case data included address, postcode, sex, age, NHS number, occupation, and the test date.

"Subject to necessary data safeguards, we will enhance the level of this detail to ensure that local public health teams on the ground have the information they need to fight this virus," the spokesperson said, adding that translation services were "fully live" and available in more than 200 languages. 
1 Department of Health and Social Care. NHS Test and Trace-week eight of contact tracing, England: 16 July-22 July. Jul 2020. https://assets.publishing.service.gov.uk/government/uploads/system/uploads/attachment_data/file/905231/Test_and_trace_week8_finaL_accessible.pdf.

This article is made freely available for use in accordance with BMJ's website terms and conditions for the duration of the covid-19 pandemic or until otherwise determined by BMJ. You may use, download and print the article for any lawful, non-commercial purpose (including text and data mining) provided that all copyright notices and trade marks are retained. 